Muséologies

Les cahiers d'études supérieures

muséologies

\title{
Creative practice to encourage imagination and sharing stories in museum settings
}

\section{Caroline Claisse}

Volume 8, numéro 1, 2015

Réflexions sur la pratique curatoriale et la recherche-création

URI : https://id.erudit.org/iderudit/1034615ar

DOI : https://doi.org/10.7202/1034615ar

Aller au sommaire du numéro

Éditeur(s)

Association Québécoise de Promotion des Recherches Étudiantes en Muséologie (AQPREM)

ISSN

1718-5181 (imprimé)

1929-7815 (numérique)

Découvrir la revue

Citer ce compte rendu

Claisse, C. (2015). Compte rendu de [Creative practice to encourage imagination and sharing stories in museum settings]. Muséologies, 8(1), 147-170.

https://doi.org/10.7202/1034615ar

Tous droits réservés (C Association Québécoise de Promotion des Recherches Étudiantes en Muséologie (AQPREM), 2016
Ce document est protégé par la loi sur le droit d'auteur. L’utilisation des services d'Érudit (y compris la reproduction) est assujettie à sa politique d'utilisation que vous pouvez consulter en ligne.

https://apropos.erudit.org/fr/usagers/politique-dutilisation/ 
Carnet un

Creative practice to encourage imagination and sharing stories in museum settings

Caroline Claisse 
Caroline Claisse works across the field of design, research and art. With a background in fine arts and graphic design, she recently graduated from the MA Information Experience Design at the Royal College of Art in London where she now teaches as a visiting lecturer. Her design practice specialises in museums, storytelling through space and visitors' engagement. Starting at the Museum of Modern Art (New York) in 2010, she has since developed exhibitions and interpretive works for Historical Royal Palaces, English Heritage and National Trust sites. While presenting her research at various conferences, she has recently worked with art galleries and schools to run workshops and create participatory artwork. 


\section{Resume}

The paper summarises both research and creative practice undertaken during the second year of my MA Information Experience Design at the Royal College of Art (London, UK). The MA course promotes the use of design research in order to maintain a constant and iterative dialogue between research and creative practice. Thus, it encourages students to ground their practice in research theory and methods, while maintaining and encouraging a high degree of creativity and experimentation ${ }^{1}$. The work introduced in this paper aims to show how creative practice can encourage imagination and sharing stories through the creation and use of tangible materials. Three sections structure the paper from research to practice, they are summarised below:

Background Research, briefly introduces my MA dissertation "Interpretive handling objects for mediating experiential learning in gallery settings ${ }^{2 "}$. The dissertation investigated how creative practitioners mediate between a museum and its visitors through the use of interpretive handling objects to provide the visitors with possibilities for sensory exploration, leading to new ways to connect with the work on display. The research focused on the case study of the Object Dialogue Box ${ }^{3}-$ a collection of artist-created interpretive handling objects used in gallery settings to facilitate experiential learning. Created for different cultural institutions by Karl and Kimberley Foster under the artistic partnership of hedsor, the Object Dialogue Box can be used as an alternative method to enable visitors to express and share their experience and perspectives between each other and with the institution. This example used in my dissertation demonstrated the potential of touch in gallery settings and how experiential learning can be encouraged through creative, participatory and tactile experiences.

Design Experiment presents The Monk's Parlour Kit, a tool-kit designed to encourage participants' meaning-making in a museum context. It featured a series of hands-on activities which were conducted in April 2014 within the John Soane Museum ${ }^{4}$ in London. Following a visit to The Monk's Parlour, a room located in the basement of the museum, eight participants used the kit to reflect on their visit through the creation of expressive artefacts which promoted conversation between myself and each participant. The experiment is introduced in this section to show how through making, meaningful and personal insights can be brought to surface.

Experimental Installation presents The Exquisite Cabinet, an installation first exhibited at the 2014 Royal College of Art degree show in London. The cabinet featured four curious objects in which users were invited

1 Royal College of Art. Information Experience Design. (accessed May 2015)

2 CLAISSE, Caroline. Interpretive Handling Object for Mediating Experiential Learning in Gallery Settings. MA Dissertation. Information Experience Design, Royal College of Art, London, October 2014.
3 Hedsor. The Object Dialogue Box. (19 $9^{\text {th }}$ May 2015). http://www.objectdialoguebox.com/

4 The Monk's Parlour Kit was conducted without the institution's involvement. 
to embed snippets of stories. In order to encourage imagination and the sharing of stories, the installation used methods borrowed from the surrealist art movement such as the game "Exquisite Corpse" and the use of hybrid objects. During the show the cabinet collected stories generated by the public for each object which were both printed and digitally stored. In this paper, the three sections attempt to show the connections between how both research and experiment fed into the final installation: The Exquisite Cabinet.

\section{Background Research - Dissertation}

My MA dissertation ${ }^{5}$ investigated the increasing role of museums in enhancing visitors' learning experiences through creative and unfamiliar use of their space and collection. It focused on the case study of the Object Dialogue Box ${ }^{6}$, a collection of interpretive handling objects used in gallery settings to provide visitors with new ways of stimulating meaning-making. This section introduces a brief overview of both theoretical background and dissertation's case study in order to emphasise the potential of creative, participatory and tactile experiences in gallery settings.

\section{Theoretical Background}

In the context of this research it was necessary to review learning through different perspectives which both question and expand on traditional models of transmission-based learning.

To support the dissertation case study, the perspectives of John Dewey ${ }^{7}$ and his work on experiential learning were highlighted. Dewey stresses the value of experience for learning and emphasises that direct experience facilitates meaning-making. He also emphasises the relationship between the eye and the hand as being "instrumental to each other ${ }^{8 "}$ :

As we manipulate, we touch and feel, as we look, we see; as we listen, we hear. The hand moves with etching needle or with brush. The eye attends and reports the consequence of what is done. Because of this intimate connection, subsequent doing is cumulative and not a matter of caprice nor yet of routine. In an empathic artistic-esthetic experience, the relation is so close that it controls simultaneously both the doing and the perception?.

Another key reference which supported the research is Howard Gardner and his theory of multiple intelligences introduced with his book ${ }^{10}$ where

5 CLAISSE, Caroline. Interpretive Handling Object for Mediating Experiential Learning in Gallery Settings. MA Dissertation. Information Experience Design, Royal College of Art, London, October 2014.

6 HEDSOR. The Object Dialogue Box. (19 $9^{\text {th }}$ May 2015).

7 DEWEY, John. Art as Experience. New York: Perigee Books, 2009 (@1934 by John Dewey).
8 Ibid., p. 50.

9 Ibid., p. 49-50.

10 GARNER, Howard. Frames of Mind: The Theory of Multiple Intelligences. New York: Basic Books, 2011 (๔ 1983, 2004, 2011 by Howard Gardner). 
he rejects the single model of intelligence in favour of different types which are primarily sensory, involved in constructing personal meaning and stimulating performance, creativity and exploration. For example, one intelligence is described as bodily-kinesthetic where mental and physical activity are seen as related. Finally, the "Constructivist Museum" described by George Hein ${ }^{11}$ shows the need for museums to reconsider how learning takes place within their walls and through their collections. Hein originally refers to the work of Jean Piaget who claims that learners do not simply add information, facts and experience to a tabula rasa, which results in knowledge; rather, they construct knowledge as they learn-"they constantly reorganise and create both understanding and the ability to learn as they interact with the world ${ }^{12 "}$. My research is informed by these different perspectives on learning: some focus on hands-on experience, and look for hidden meaning; others investigate learning by feeling, watching, listening and sharing ideas with interpretation that encourages social interaction and the quest for personal meaning. These sources supported the analysis of the dissertation's case study further described in this section.

Focusing on the case study of the Object Dialogue Box-a collection of artist-created interpretive handling objects, the dissertation research also investigated the potential of touch in gallery settings. The "hands off" experience is usually the number one rule visitors encounter in today's museums where artefacts are expected to be seen, not touched. However, Constance Classen ${ }^{13}$ demonstrates evidence that visitors to museums in the seventeenth and eighteenth centuries were able to touch objects on display. She shows various examples and highlights the potential of touch in bringing the museum to life ${ }^{14}$ by creating intimate, physical and emotional connections with artefacts on display. Classen's research shows early consideration for touch in gallery settings, she quotes Robert Mandrou ${ }^{15}$

Until the eighteenth century at least, touch remained one of the master senses. It checked and confirmed what sight could only bring to one's notice. It verified perception, giving solidity to the impressions provided by the other senses, which were not as reliable.

Although, she argues that the investigation of touch in gallery settings shifted in the eighteenth century with modern scientific inquiry where "the important thing in modernity was to $\operatorname{see}^{16 "}$. Conservation concerns and increasing number of visitors to museums also justified the transformation of the museum from multi-sensory to purely visual site.

11 HEIN, George. Learning in the Museum. London: Routledge, 1998, p. 155.

12 HEIN, George. "The Constructivist Museum". Journal for Education in Museum. No. 16: 21-23, 1995, p. 4.
13 CLASSEN, Constance. "Museum Manners: The Sensory Life of the Early Museum”. Journal of Social History. Vol. 40, no. 4, Summer 2007, p. 895-914.

14 Ibid., p. 903.

15 Ibid., p. 276.

16 Ibid., p. 907. 
In terms of art practice, the act of touch as a way of transferring meaning has been explored by both Surrealist and Dadaist artists who played with the tactile mode of interaction, and proposed new sensory experiences to the viewer. This is what Janine Mileaf investigates in her book "Please Touch ${ }^{17 "}$ where she notices the growing interest in tactile property by early $20^{\text {th }}$ century art movements. Fiona Candlin ${ }^{18}$ also notes the increasing acknowledgement for touch in museum context. She describes several examples such as a dedicated touch gallery at Wolverhampton Art Gallery, and the fragile work of artist Eva Hesse, made available to touch at Tate Modern. In her research, Candlin refers to embodiment theorists who argue that the nature of the human mind is largely determined by the form of the human body. For example, aspects of cognition such as concept formation and reasoning can be influenced by the body's interaction with the environment. Theorists such as Merleau-Ponty have argued that knowledge is not detached from the body and the body is the ground of culture and thought ${ }^{19}$. However, while Candlin notices the increasing access of touch in the museum, she argues that this level of access can be sometimes merely palliative ${ }^{20}$. She criticises the fact that under such supervised circumstances as handling sessions, people are not given much permission, choice or control about what they can touch. Indeed, touch is rarely encouraged outside of these supervised and occasional handling sessions or specific tours. In this case, it is not used as a means of learning but only as a way of looking more closely at a work on display. Rather, she encourages museums to develop haptic experiences as a source of knowledge and pleasure in their own right ${ }^{21}$.

\section{The Object Dialogue Box}

The Object Dialogue Box (ODB) was used as a case study for my MA dissertation. The research shown one session of the ODB used in the context of Turner Contemporary (Margate, UK). It was based on my direct observations and aimed to answer the following research question: how does a tool such as the ODB mediate visitors' experiential learning with artefacts in gallery settings? In terms of methodology, I used Activity Theory ${ }^{22}$ as a frame for studying how museum visitors make meaning when using the ODB. More specifically, the Activity Checklist ${ }^{23}$ guided the evaluation of the ODB used in the context of Turner Contemporary. However, for the purpose of this paper, only a brief introduction of the dissertation case study is described below.

17 MILEAF, Janine. Please Touch, Dada and Surrealist Objects after the Readymade. United States: Darmouth College Press, 2010.

18 CANDLIN, Fiona. "Don't Touch! Hands off! Art, blindness and the conversation of expertise". Body \& Society

10. London: Birkbeck ePrints. http://eprints.bbk.ac.uk/775/

19 Ibid., p. 2.

20 Ibid.
21 Ibid., p. 3.

22 KAPTELININ, Victor \& Bonnie A. NARDI. Acting With Technology. Activity Theory and Interaction Design. London: The MIT Press, 2010.

23 KAPTELININ, Victor and Bonnie A. NARDI and Catriona MACAULAY. "The Activity Checklist: A Tool for Representing the Space of Context”. Interactions. Vol. 6, Issue 4, July-August, 1999, p. 27-39. 
Over the past ten years, the creative practitioners Karl and Kimberley Foster, under the artistic partnership of hedsor, have created around ten Object Dialogue Boxes for different cultural institutions including museums, libraries and contemporary art galleries. Having an Object Dialogue Box and using it regularly is emblematic of "dynamic, fluid and creative learning ${ }^{24 "}$. One of the most important elements behind the ODB is the idea of ownership, and how museums can take on something they can manipulate and change. The Object Dialogue Box is intended to support and allow creativity, research and artistic practice to be a vital element of the museum's space. Described as a "surreal manifestation ${ }^{25 ",}$, it often consists of twenty unusual or unfamiliar objects that work as interpretive devices. Figure 1 shows the facilitator checking the objects within the box before the session starts.

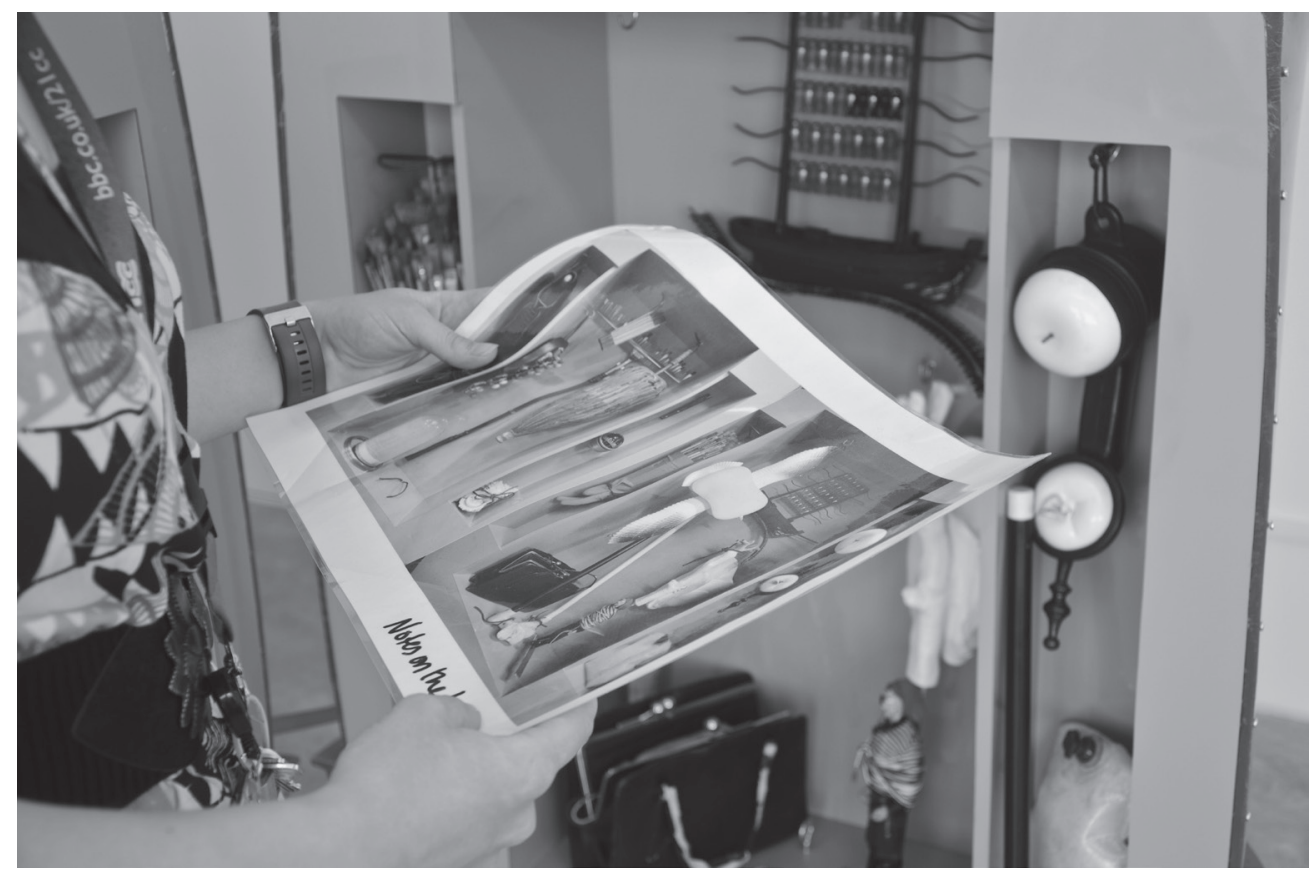

Figure 1

Facilitator checking the Object Dialogue Box before session. Turner Contemporary, July 2013.

[Photographer: Caroline Claisse].

The objects within the box are unusual within the museum context because they can be touched, so visitors may handle them while walking around the gallery. According to the artists, the objects have dual functions, as they are artworks that can also be handled and

24 FOSTER, Karl \& Kimberley. "The importance of the unfamiliar and unexpected in creative teaching, interpretation, and learning”. In. MILLER, Alisa SHARP, John and STRONG, Jeremy (dir.). What is research-led teaching? Multi-disciplinary perspectives. London: CREST, 2012, p. 110.

25 Ibid., p. 106. 
used: "They meet aesthetic conventions as art objects, whilst offering use as catalysts to facilitate, or stimulate, learning and interpretation in a plethora of settings ${ }^{26 "}$. The objects are stored in a box and both contents and container are influenced by the place they are commissioned for. The study focused on one box commissioned in 2010 by the visual arts organisation Turner Contemporary in Margate (UK). The box is a modified marker buoy and has a relevant narrative to the context of the art gallery which faces the sea. hedsor adopted a collaborative approach in which both gallery staff and teachers were solicited in the making of the box. Their experience of the gallery was first used to produce a list of thematic words. The next step started with what the artists call the "cooking metaphor", in which all the elements blend together. The artists explain some of this process:

The words were sent to us and were tacked to the wall of the studio as a "constellation", or a visual map. Usually, we buy materials that sit within this constellation of words, that is, they have a semantic resonance with them. In the studio we start to re-constellate the objects/materials with words so that there is a material and textual merging and reconfiguration. At this point, the process of de-familiarisation begins ${ }^{27}$.

This process results in objects that are not easily recognisable or nameable. For example, the box at Turner Contemporary features one object which is an hybrid between a seagull and a sponge (Figure 2). The artists explained the process of creating this object:

There is a problem with seagulls in Margate, they are regarded as pests and you are not allowed to feed them. We bought a plastic seagull because one of the words that was sent to us by the gallery was the word "seagull". On the wall of the studio this word was placed by coincidence near a sponge on a shelf. Another phrase nearby on the wall was "drawn to water". Having these three elements in the space was pure accident, but the idea of a seagull and a sponge as one "being" was interesting. The seagulls are drawn to water but need to fly and exist on land. We decided to make the seagull fit inside a sponge so that its wings, head and tail feathers protrude. One might call it a seagull suit. The seagull gets embroiled in the magnetic metaphor between the sea and the sponge, the sponge potentially absorbing the water and hampering the ability of the seagull to fly. In terms of nomenclature, when the two elements are merged together the distinct terms of 'seagull' and sponge are thrown into question. I glued them in a way that you cannot see the separation between the two ${ }^{28}$.

27 CLAISSE, Caroline. Interpretive Handling Object for

Mediating Experiential Learning in Gallery Settings. MA

Dissertation. Information Experience Design, Royal College of Art, London, October 2014, p. 18. 


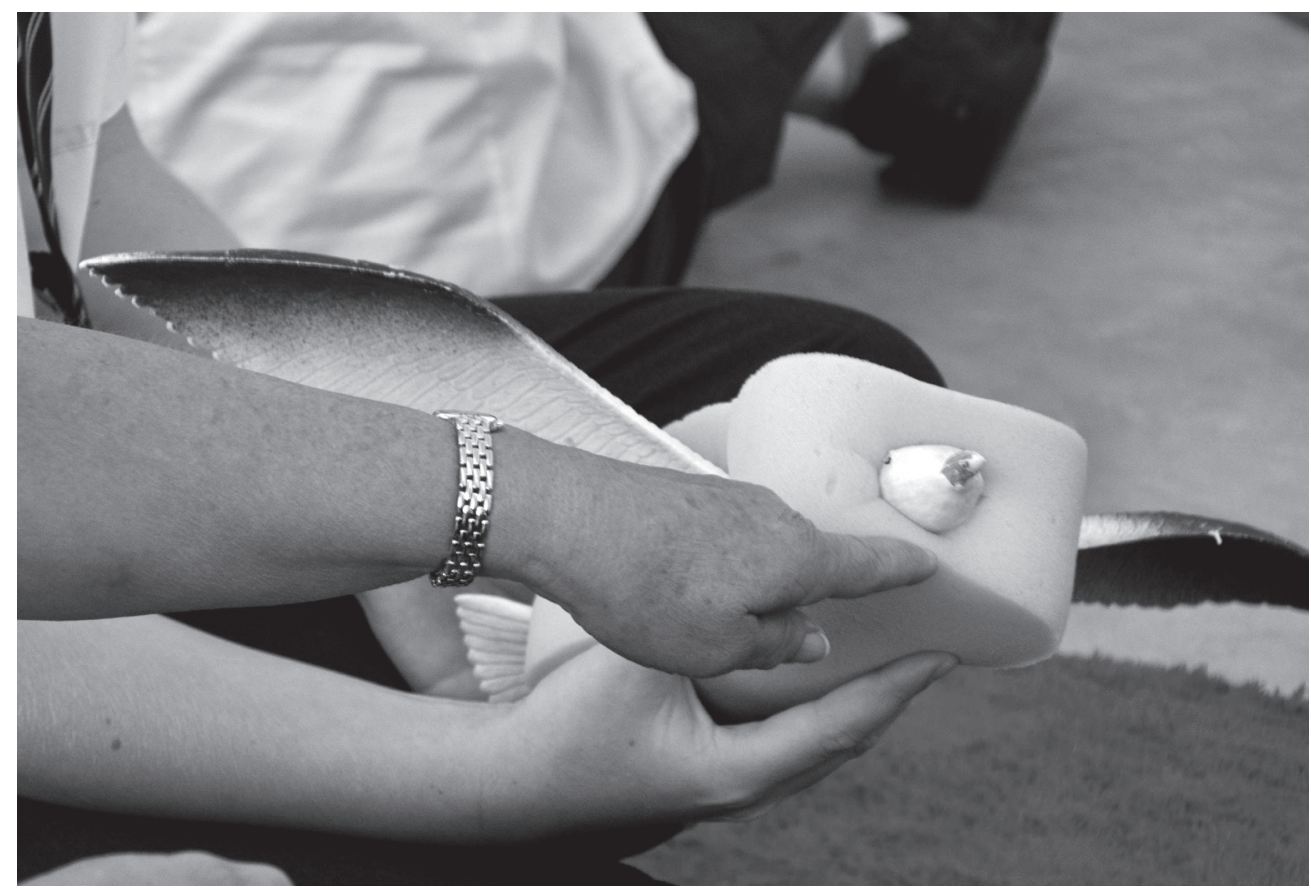

Figure 2

Participants holding one object from the box. Turner Contemporary, July 2013.

[Photographer: Caroline Claisse].

One of the most important element behind the ODB is the idea of ownership, and how the museum can take on something they can manipulate and change. Once delivered to the institution, the museum takes ownership of the box. The ODB does not intend to replace any kind of traditional learning approaches in the museum but rather, to propose something additional that can enhance the conventional experience of meaning making in gallery settings. For example, at Turner Contemporary, the ODB is used to encourage the audience to think like artists, to take risks and to experiment through dialogue and creative enquiry where there is no right or wrong answer ${ }^{29}$. The objects created by hedsor are not intended to mediate any specific facts for people to learn, but to invite them to make meanings by providing opportunities to access the artefacts on display, from their own artistic perspective. The objects in the box are unfamiliar; they present an interpretive challenge to the museum visitors, which should enable them to reconsider the objects on display. Indeed the artists explained the potential of using the box in gallery settings is to challenge what has been overlooked to be reconsidered, to be seen afresh, which in turn enables new understandings to emerge ${ }^{30}$. 
In the context of Turner Contemporary, the use of the ODB started in a separate room with a group of 15 participants and was led by a facilitator. The box was first presented closed in order for participants to guess what was inside (Figure 3).

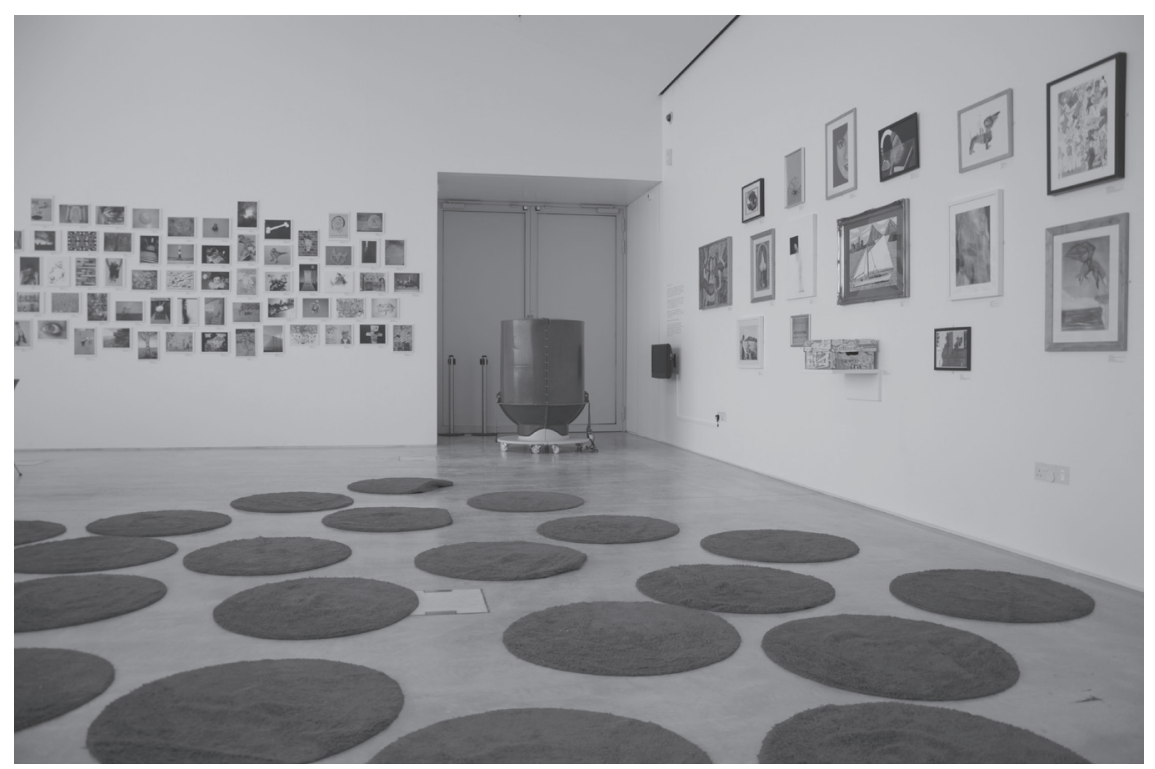

Figure 3

The Object Dialogue Box before the session. Turner Contemporary, July 2013.

[Photographer: Caroline Claisse].

Once opened, participants could choose one or several objects in order to discuss them between each other and exploration through touch was encouraged. During the session, participants were invited to walk around the exhibition space while handling their chosen object. In this case, they were asked to find connections between their object and the work on display. For the facilitator, using the ODB generally increases dialogue, imagination and confidence but also encourages participants to think like artists. After the session, she explained:

We found quite often that when people come to the gallery, they have questions but they don't have enough confidence to ask them and to talk about them because they think it might be stupid questions. So, having the Object Dialogue Box encourages people talking about art and asking those questions in a context where there is no right or wrong answer ${ }^{31}$.

The observation from the case study shown that enabling proximity through touch and fostering exploration were two key aspects by which the ODB mediated visitors' experiential learning. Being able to 
touch objects increased a sense of discovery and curiosity between the participants. According to the artists, people understand the objects better when they touch them. For them, touch communicates all sorts of things:

The relationship between this kind of physical interaction and what happens in the brain is fascinating. A physical exploration of the materiality of an object seems to affect the type of language used in dialogue that might happen around it. When people have got something delicate in their hands, body language changes and spoken language changes. Delicate objects seem to bring about delicate discussion ${ }^{32}$.

From my own perspective, the study enabled me to understand different aspects of mediating experiential learning and facilitating meaning-making with interpretive objects in gallery settings. In the context of my own practice, this presented and informed my work to think about tools such as interpretive handling objects and how they might mediate experiential learning when augmented with digital technology. This is discussed in the last section of this paper.

\section{Design Experiment - The Monk's Parlour Kit}

This design experiment was conducted within the John Soane Museum (London, UK). The museum is the home of the architect and collector Sir John Soane and is described as "a labyrinth of glittering mirrors, hidden passages, concealed skylights, and secret niches ${ }^{33 \prime}$. The small experiment was run as part of my MA research with eight participants but with no direct involvement from the museum. It was motivated by looking at how museum visitors could make meaning of their experience of a space through a structured and creative construction activity, focusing on elements from the space that are meaningful to them. This section introduces the kit and some theoretical background which supports the experiment.

\section{The Monk's Parlour Kit}

The experiment took place in one particular room of John Soane Museum: The Monk's Parlour, located in the museum's basement. Usually, visitors are allowed in small groups within this room, they cannot take any photographs and can only sketch with a pencil. The space is very theatrical and resplendent with objects and very few labels interpretations describe the origins and stories of the space. The museum facilitator standing by the entrance described the original use of the room where the architect would receive his guests for tea. The config- 
uration of the space is shown in Figure 4: a dramatic contrast between high and low ceiling where a melancholic atmosphere dominates characterised by the abundance of Gothic decoration.
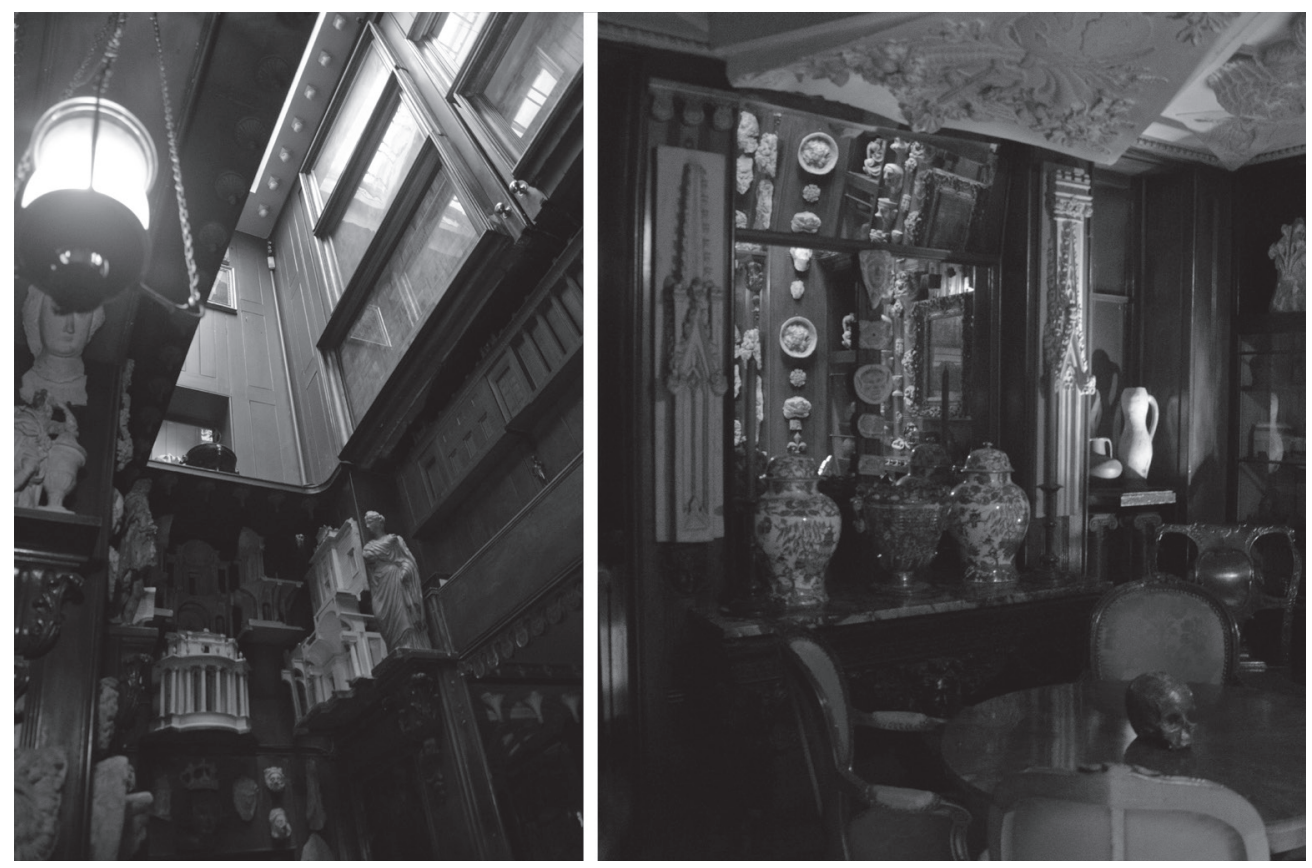

Figure 4

The Monk's Parlour Room. John Soane Museum. March 2014.

[Photographer: Caroline Claisse].

With The Monk's Parlour Kit, I was interested in creating tools to encourage creative thinking in order to stimulate participants' meaning-making in a museum context. The kit was designed to provide a group of participants with external support to challenge them to translate and transform both their ideas and experience of a space into tangible forms. The experiment took place in three stages: first, participants were given one kit each (Figure 5) and were asked to visit the Monk's Parlour Room at the John Soane Museum. Then, there were activities conducted during and after participants' museum visit. Lastly, I met with each of them to discuss both their experience of the space and the kind of materials generated from the kit. Participants were eight adults, MA and PhD students from the Royal College of Art -an admittedly limited and specific user group. The kit had a structure, starting with two dimensional basic tasks, progressing towards more complex and abstract three dimensional tasks. 


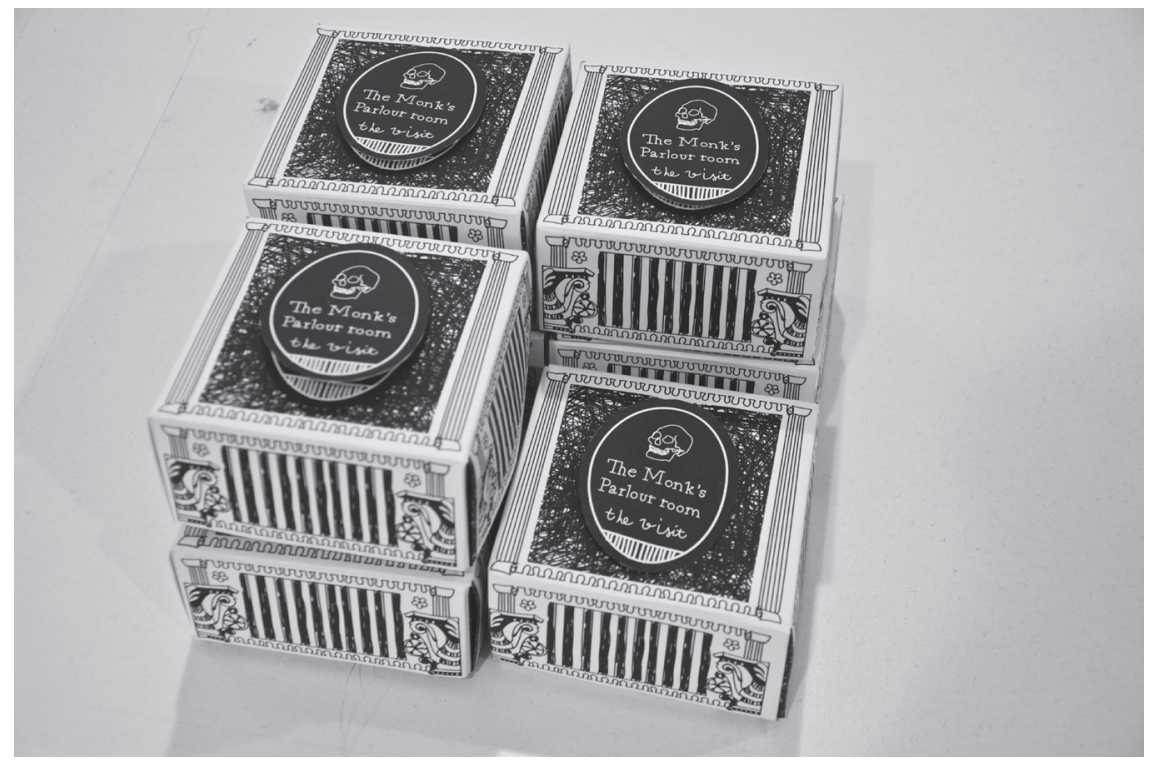

Figure 5

The Monk's Parlour Kit. March 2014.

[Photographer: Caroline Claisse].

First, when opening the kit, participants could find a key ring (Figure 6) which revealed a kind of narrative to help immerse participants in the activity e.g. Sir John Soane left for his Grand Tour in Italy, and he needs you to complete the following tasks while he is away. The kit featured basic materials for participants to use such as a small sketchbook, one Fimo pack (modeling clay), an empty container and small pieces of pre-cut foam boards. Participants were free to organise themselves as they wanted but most of them completed the tasks after their visit of the museum for practical reasons. The kit started with basic tasks: "How is the Monk's Parlour Room organised? Draw a map (1)" and "What can you see on the walls? Sketch an elevation of the room (2)". This enabled participants to become more familiar with the space. Then, more abstract and poetic representations of the space were encouraged: "What does the room feel like? Document the light in the room (3)" and "Pick an object, draw or write about it. Use the Fimo pack to model a small version of it (4)". Then, more three-dimensional tasks challenged participants to narrow down their interpretation of the space: "If you could have taken away three things from the room, what would they be? Capture and place them within the container (5)" and "Use the pre-cut pieces of foam boards to create a small version of your own representation of the room (6)". Participants produced a very diverse repertoire of representations, from realistic to more structured to completely abstracted interpretations of the space. 


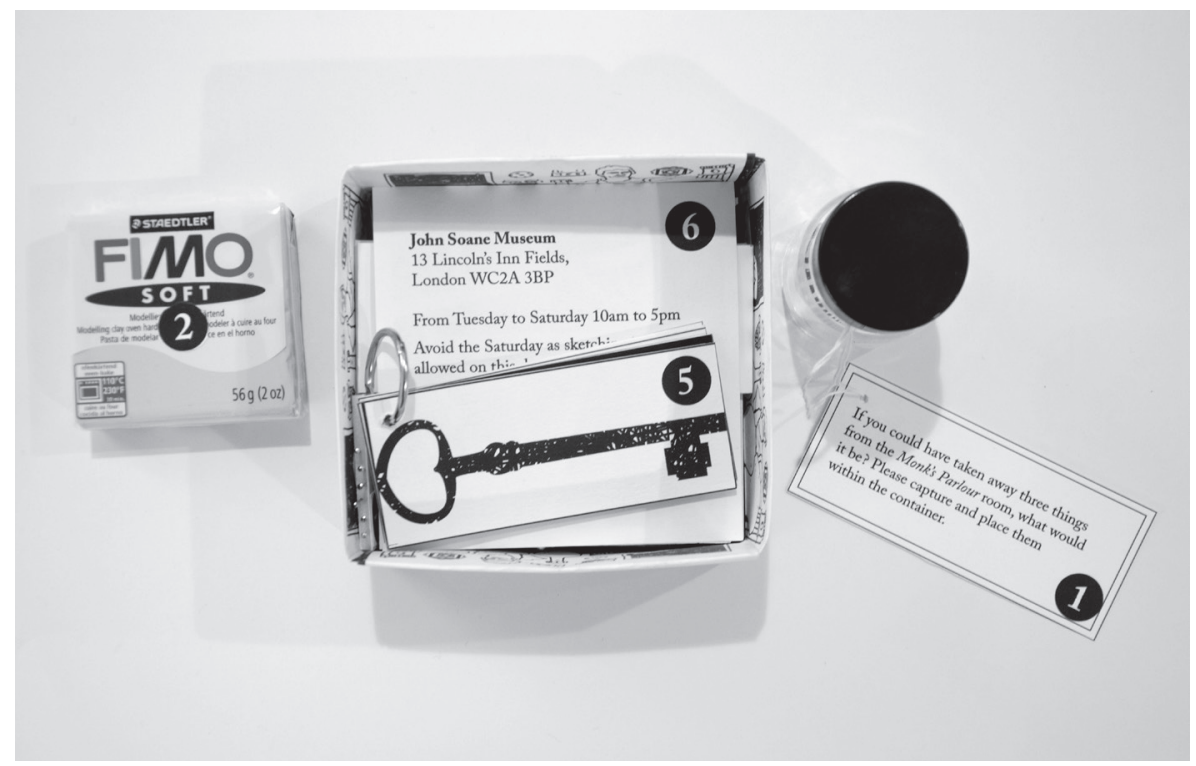

\section{Figure 6}

The Monk's Parlour Kit, opened. March 2014.

[Photographer: Caroline Claisse].

Figure 7 shows how the kit had channeled one participant's creativity through the different steps of the activity to achieve a surprising and valuable outcome. The participant first drew attention to one element in the room: the paintings, an element he overemphasized by drawing many of them. From the painting he focused on the frames and compared them to "a portal to another space in the museum". This surreal and spatio-temporal element is interesting in the context of John Soane who collected thousands of objects from various places and time periods. Indeed, being in the museum feels a bit like jumping from different time periods when moving from one room to another. With the following tasks, the participant re-visited his idea and understanding through different materials, and so generated an original and more intricate understanding of the space through creative exploration. He explained how he abstracted the model at the end, and mentioned "these little doors" though which you can see the Picture Room, another room in the museum just above the Monk's Parlour. He described more of his process:

This a painting. It is one of many in the Monk's Parlour. Its specificity is lost among the numerous paintings in the room. The framed rectangular objects become an architectural feature in their own right, they mosaic the walls as a collective decoration. The glazing over the paintings reflects the light within the space so really it does not matter what is behind the glass. The details in the image is lost. They are mirrors and paintings simultaneously ${ }^{34}$. 

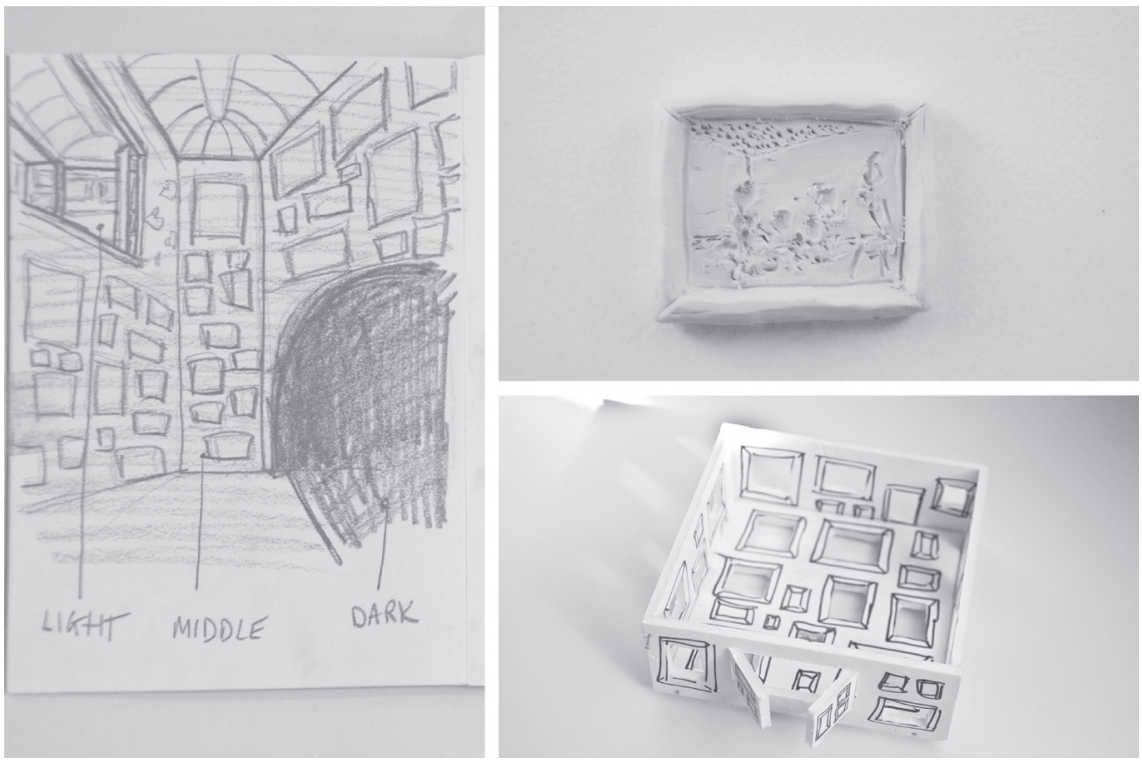

Figure 7

Materials generated from the kit for one participant. March 2014.

[Photographer: Caroline Claisse].

Finally, the participant described how the structure of the kit helped to mediate his process:

I was very measured the way I did things at the start but as the project went along I got more creative. It was interesting to do the activity as a whole as I went through all the parts it got more interesting to me. I was able to pin down what element in the space was that stood out to me. First thing was to look at all the bits and then it got more specific to me.

In most cases, the use of the kit helped participants to create more personal and imaginative responses. For example, the use of different materials increased visitors' attention to the different textures and sensory qualities in the space. For the task where participants were asked to capture three elements, one selected a piece of mirror, one match and air to be placed within the container. She explained:

Three things I want to take away is the air, 50 cc of the Monk's Parlour Room. It is like Duchamp's $50 \mathrm{cc}$ of Paris air (...). And then the match means to bring up the light in the space and finally the mirror, very high quality mirror in the dark, especially the one behind the table.

The participant made a personal and strong statement by quoting Duchamp's empty ampoule artwork (1919). By picking one match and a fragment of a mirror she referred to her favourite architectural features of the Monk's Parlour room: light and reflection. Having their tangible materials in the post-visit interview helped them to talk about 
their experience of the space. It also made them more confident and supported their interpretations. Another participant concluded:

The chance to actually go there with a focus was actually really interesting... It is really important to work out what things mean the most to you, so many things in there, there are so much, so it [the kit] makes you think about what is it that has an impact on you.

\section{Theoretical background}

With The Monk's Parlour Kit, I was interested in creating tools to encourage creativity and imagination in order to stimulate participants' meaning-making in a museum context, based on constructionist principles. The kit was designed to provide a group of participants with external support to challenge them to translate and transform both their ideas and experience of a space into tangible forms. Participants' creations acted as "objects-to-think with ${ }^{35 "}$ and encouraged conversation, opening a dialogue from someone's own perspective which facilitated new ideas to emerge. Informed by Seymour Papert's constructionist approach to learning, this experiment looked at the importance of learning through making, in being active rather than passive. Edith Ackermann ${ }^{36}$ highlights the importance of externalising our ideas into tangible forms in order to be communicated and shared with others. This illustrates how constructionist learning theory is informed by Piaget's constructivism. Both have a common ground but differ in the following way:

Constructivism talks about the invisible construction of ideas, and relations among ideas, within the mind of the learner.

Constructionism adds to that the idea that /external/construction of real artifacts is a powerful means to achieve Piaget's internal construction of understanding ${ }^{37}$.

Yasmin Kafai ${ }^{38}$ argues that constructionism places emphasis on knowledge construction that takes place when learners are engaged in building objects. She argues that it encourages personal affect, new relationships with knowledge and multiple learning styles. She also emphasises a strong connection between design and learning. For a long time, design and learning differed from each other: for example, design was primarily interested in final products, while learning focused on process. This can still happen but Kafai argues that they have moved towards each other: "Design is now viewed as the process through which a designer comes to understand not only objective constraints, but also subjective meanings ${ }^{39 "}$. On the other hand, the education

35 ACKERMANN, Edith. "Piaget's Constructivism, Papert's Constructionism: What's the Difference?”.

MIT Media Lab Publications, (Accessed May 2015).

36 Ibid.

37 Constructionism 2014. Constructionism and Creativity

Conference. (Accessed August 2014)
38 KAFAI, Yasmin B. Constructionism in Practice: Designing, Thinking, and Learning in A Digital World. New Jersey: Routledge, 1996, p. 4. 39 Ibid. 
system has started to pay more attention to the role of the artefact and this results in the following conclusion: "Meaning-construction happens particularly well when learners are engaged in building external and sharable artifacts $^{40 "}$.

More recently Elizabeth Sanders and Pieter Jan Stappers talk about the changing role of making in design process: "Today making has become an activity that both designers and co-designers can engage in during all phases of the process (...) In making people can bring their insights to the surface ${ }^{41 "}$. They present a framework which describes the different approaches to be adopted through the four phases of the design process: pre-design, generative, evaluative and post-design. One participative approach they introduce is called a generative toolkit and is used in the generative phase of the design process to create expressive artefacts. This characterises approach such as the Monk's Parlour Kit which informed the next phase (evaluative) with the prototype of The Exquisite Cabinet described below in Section IV.

\section{Experimental Installation - The Exquisite Cabinet}

The Exquisite Cabinet was an experimental installation exhibited for two weeks at the 2014 Royal College of Art (RCA) degree show. Following from previous research, it explored how objects can encourage imagination and, how technology can allow for collecting and sharing stories. The cabinet used Radio-frequency identification (RFID) technology so users could record snippet of story for each object which were then printed from the back of the cabinet. In order to encourage imagination, the cabinet used methods borrowed from the Surrealist art movement. This section details both the making process of the cabinet and the data collected from the two weeks exhibition.

\section{Making Process of the Cabinet}

Following from my dissertation research introduced in Section II, I carried on looking at how museums use handling objects in interesting ways. I visited regularly the Horniman Museum in London which has an amazing collection of handling objects that visitors can play with in discovery sessions ${ }^{42}$. There are thousands of well crafted, fragile and precious artefacts on display in the hands-on-base space that visitors can access and handle freely. I carried out two informal observation sessions where one of the challenge museum's facilitators mentioned was the difficulty to get visitors' imagination and curiosity going with the handling objects. This pushed me to think about ways to encourage people's imagination and curiosity with the help of objects.

40 Ibid.

41 SANDERS, Elizabeth B.-N and Pieter Jan STAPPERS.

"Probes, toolkits and prototypes: three approaches to making in codesigning". CoDesign: International Journal of CoCreation in Design and the Arts. 10:1, 5-14, 2014, p. 6.
42 Horniman Museum. Hands on Base. http://www.horniman.ac.uk/visit/displays/hands-on-base\#image-0 
The Exquisite Cabinet was strongly influenced by the foregoing research and experimentation. The installation featured four curious objects placed in a cabinet that users could handle freely. The objects were informed by the previous design experiment The Monk's Parlour $\mathrm{Kit}^{43}$ introduced in Section III. The kit was first designed with the aim of collecting participants' experience and understanding of one specific space. However, as the experiment went along I got more creative as well, as participants' responses and creations then informed my own artistic practice and meaning-making in relation to the space. Following from participants' interviews, I collected both keywords and materials to create a series of my own curious object in response to the Monk's Parlour space. The creative process was informed by the case study of my dissertation, The Object Dialogue Box ${ }^{44}$ where the artists adopted a participative approach for the making of their objects. For example, they collected keywords from the gallery staff about the gallery space in order to inform their making process. I adopted a similar approach with The Monk's Parlour Kit where I was interested in others' interpretation of one specific space: The Monk's Parlour. Indeed, by designing the kit and collecting the materials generated by participants, I learned about John Soane himself. He was a compulsive collector, so I wanted to create a series of objects that he might have owned, but rather than teaching about architecture and taste, the objects would act as intriguing tools to stimulate imagination and stories. Figure 8 shows the final four objects inspired by John Soane and used in the cabinet at the RCA degree show.

To some extent, the four objects featured in The Exquisite Cabinet were informed by interviews conducted with participants who completed the Monk's Parlour Kit described in Section III. For example, the first object \#1 (far left on Figure 8) represents a small dog in a broken champagne glass attached to a balloon. This could echo Soane's taste for champagne and the numerous parties he held in the basement of his house. It is believed that the dog he owned was buried in front of the Monk's Parlour room in the Monk's Yard with fragments of a champagne bottle as a decoration in the ground. The second object \#2 (next to \#1 on Figure 8), is an hybrid between a cup and a handcuff. This object could refer directly to the ritual of Soane inviting his guests in the room for a cup of tea. The handcuff attached to the cup symbolised Soane's isolation after the death of his wife: how he became himself a prisoner of the room. The following object \#3 combines a razor together with a delicate hand. In the previous experiment, one participant mentioned Soane as being a normal man of his time, having still to do his daily routines such as shaving, while living in such prestigious place (museum as a home, public vs private space). The hand stuck on the razor could echo the delicate and feminine presence of his wife or the gentleness of his friends helping Soane to overcome his wife's death. Finally object \#4 

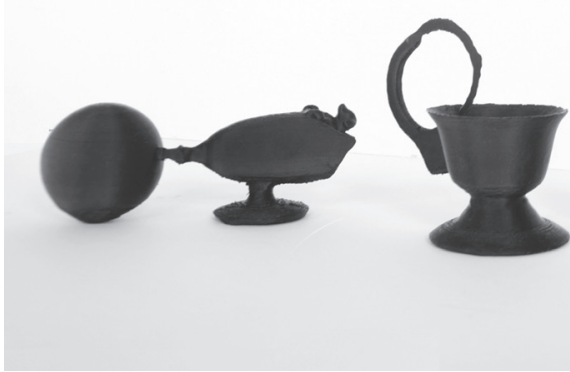

Figure 8

Four objects, The Exquisite Cabinet. June 2014.

[Photographer: Caroline Claisse].

(far right on Figure 8), represent a mask and a broken mirror.

Participants mentioned the theatricality of both the space and the objects. One person at the museum mentioned that Soane might today be diagnosed with a kind of bipolar disorder, and would hide his emotions in public. The mirror echoes his introverted personality but also the reflective qualities of the space described by one participant in the previous experiment.

\section{Data Collected from the Cabinet}

Exhibited in The Exquisite Cabinet at the RCA Degree Show, the four objects worked independently from the context of John Soane. Indeed, they were used as creative stimulus to challenge visitors' imagination in order to generate new narratives and stories for each object. The way they were made, as hybrids of two or more fragmented objects, was intended to trigger visitors' curiosity. Indeed the process of making these objects echoes Surrealist methods from the 1930s, in which artists collected found objects and re-arranged them in unexpected combinations or "poetic assemblage" that would challenge the subconscious. Surrealist poet André Breton argued that such methods can "aid the systematic derangement of all the senses... it is my opinion that we must not hesitate to bewilder sensation... ${ }^{45}$ ". Section II described briefly the Object Dialogue Box where the artists mentioned the process of de-familiarisation. Indeed, I was very inspired by their making process where they often merge objects together by gluing them in order to hide the separation between the two. This 
results in an object that is not easily recognisable or nameable and as a result, their objects used in gallery settings challenge what has been overlooked to be reconsidered and to be seen afresh, enabling new understandings to emerge. With The Exquisite Cabinet, the objects were also assembled and glued together, but then they were 3D scanned and 3D printed in one whole new object. So the handcuff in object \#2 was not anymore a distinctive element from the cup and the new object was able to acquire new meanings when used in the show. For example it became assimilated to a prisoners' cup or a magic lamp used to transport ourselves over time. Narratives started to merge to create surreal stories dealing with tea rituals and parties mixed together with prisoners in jail, also associated to idea of loneliness. Interestingly, without a direct link, the stories generated referred back to my original inspiration when creating the objects: John Soane. Below is a selection of the snippet of stories invented by users when using the object \#2:

[The cup] must have belong to a prisoner... he needed a large handle because one of his hands has seven fingers. What I fear is the cage.. so narrow I could not breathe (...) alcoholic prisoners (...) we had a cup of tea in the jail. He stayed home immobile sat all day drinking tea ${ }^{46}$.

Creative inquiry was also encouraged by using other Surrealist methods such as the game "Exquisite Corpse ${ }^{47 "}$. Surrealist artists invented this game in the 1920s, in which participants were collectively invited to assemble words or images. In the case of words, one participant starts a sentence and folds the paper, leaving only one part of the sentence visible for the next player, who can then contribute to the narrative chain. Once finished, the paper unfolds to reveal an imaginative, curious or absurd sentence collectively assembled. Indeed, this is where the game originally took its name: "the exquisite corpse will drink the new wine ${ }^{48 " ~(t r a n s l a t e d ~ f r o m ~ f r e n c h: ~ " L e ~ c a d a v r e ~ e x q u i s ~ b o i r a ~ l e ~ v i n ~}$ nouveau") was a phrase that resulted when Surrealists first played the game. The Exquisite Cabinet used the same kind of system as the Surrealist game: it contained four drawers housing each object, and when participants removed one to place it on the top of the cabinet, it prompted an embedded screen to reveal the last seven words from the previous visitor's story, so users could carry on the narrative if they wish or break it down. Seven words, rather than one, were displayed in order to facilitate the continuation of the narrative. Following the last seven words, users could embed a maximum of 100 characters, which was found to be the maximum length as visitors often wrote between 40 and 80 characters. Each object housed one radio-frequency identification (RFID) tag so each of them had its own thread of story. Generally, it was found difficult to keep the narrative going over more than ten users and the different snippets rarely formed a sensible

46 The quotes are snippet of stories stored in The Exquisite Cabinet. Object \#2.

47 Museum Of Modern Art. Exquisite Corpse. https://www. moma.org/learn/moma_learning/glossary\#exquisite-corpse
48 Museum of Modern Art. Exquisite Corpse. https://www.moma.org/learn/moma_learning/ max-ernst-levade-the-fugitive 
sentence. However, it promoted unexpected, sometimes humorous and absurd thoughts. The following snippet is collectively assembled by 12 users inspired by object \#3:

The captain shaved the sea surface. Shaving the surface was not enough he soon realised he needed reach far underneath the water in every little corner of the flat land where the slime slipped south. Suicide is painless but what if there are seven hells? there's no earthly way of knowing just exactly where we're going... Is that you always know where you came from because it always points in the wrong direction. But it guides you to a more mysterious path tree that lays in the deep forest which is from a dream of our child wizard a certain sort of wetness is perpetuated ${ }^{49}$.

The continuous story for each object was regularly printed out from the back of the cabinet on one of four small, embedded thermal printers. For example, figure 9 shows how the installation encouraged social interaction: users are embedding stories in the cabinet while one is reading aloud the printed exquisite corpse from the back of the cabinet.

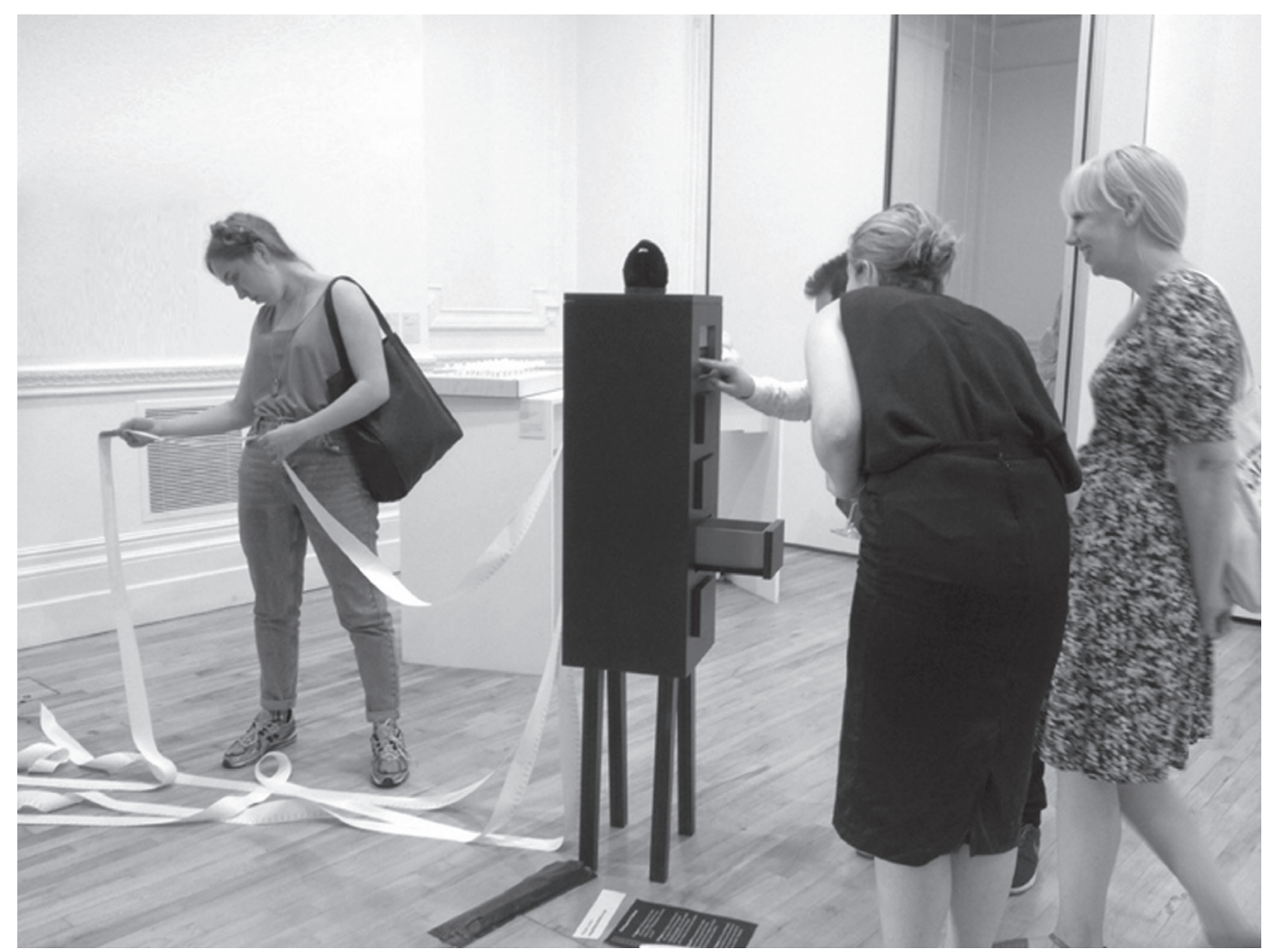

Figure 9

The Exquiste Cabinet. The Royal College of Art, June 2014.

[Photographer: Caroline Claisse]. 
The potential of touch in gallery settings was investigated through my dissertation with the case study of the Object Dialogue Box described in Section II. The handling objects encouraged engagement and demonstrated how touch can change both how people behave and talk about things: "Delicate objects seem to bring about delicate discussion ${ }^{50 "}$. Similarly, being able to touch the objects in The Exquisite Cabinet encouraged imagination, and most of the users were more precious about what to write. Over a two-week exhibition, none of the objects got stolen but the object \#2 broke about four times, due to a design fault in the cabinet in which the height of the drawers was too small for the object to be placed straight so it had to lay on its side. Most of the time users did not notice this default and closed the drawer on the handcuff, causing the object to break. It was interesting to see how these accidents influenced visitors' printed stories:

I smashed the teacup haha verrai incatenato all'acqua che ho reccolto fgh dgbb. I didn't understand what he said. I panicked, I drop the cup. she tried to save the tea from spilling etttttttddwsdfuhhbvbhufdutfyufuffgyghgfuguufkfufjchgghusaaseprdquikjhgfdfggg hhhhjjjjik koopwwwww wwww i broke a cup. Dishwasher abuser gnggng nothing to say (...) hi vodka cup, oh no the cup is broken. jen broke her cup last Wednesday (...) broken broke technology ${ }^{51}$.

Visitors were often curious about the technology used for the objects. Indeed, snippets of stories sometimes referred to the 3D printing process in which the objects were made: "Drinking from the printed cup. I am a clone with no history so sad. A three dimensionally printed digital remix of a cup and a handcuff. Creepy print ${ }^{52 "}$. The four objects were familiar enough for people to identify what they were about: "The cup looks strange because there is a handcuff stuck on the side ${ }^{53 "}$ or "Sat a strange little dog in a cup inflated by a ball of air looking out... 54". But the fact that they brought two objects in one challenged user's imaginations straight away "A dog was once sitting in a champagne glass when the bottom of the glass suddenly turned into a pea ${ }^{55 " .}$. Stories echoed cultural references throughout the narrative chain such as supernatural narratives. Following are a selection of snippets from object \#2:

(...) Some sort of magical power. A genious came out of it (...) A ghost came out of it (...) Aladdins magic lamp intriguing object. Is it an Alladin lamp? I was flying away with jafar:-) when I suddenly saw Dark Vador with a cup of wine (...) The genie has gone home but she or he has left a beautiful objet for me to admire:-- $)^{56}$

50 CLAISSE, Caroline. Interpretive Handling Object for Mediating Experiential Learning in Gallery Settings. MA Dissertation. Information Experience Design, Royal College of Art, London, October 2014, p. 20.

51 The quotes are snippet of stories stored in The Exquisite Cabinet. Object \#2.

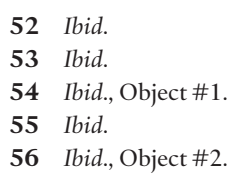




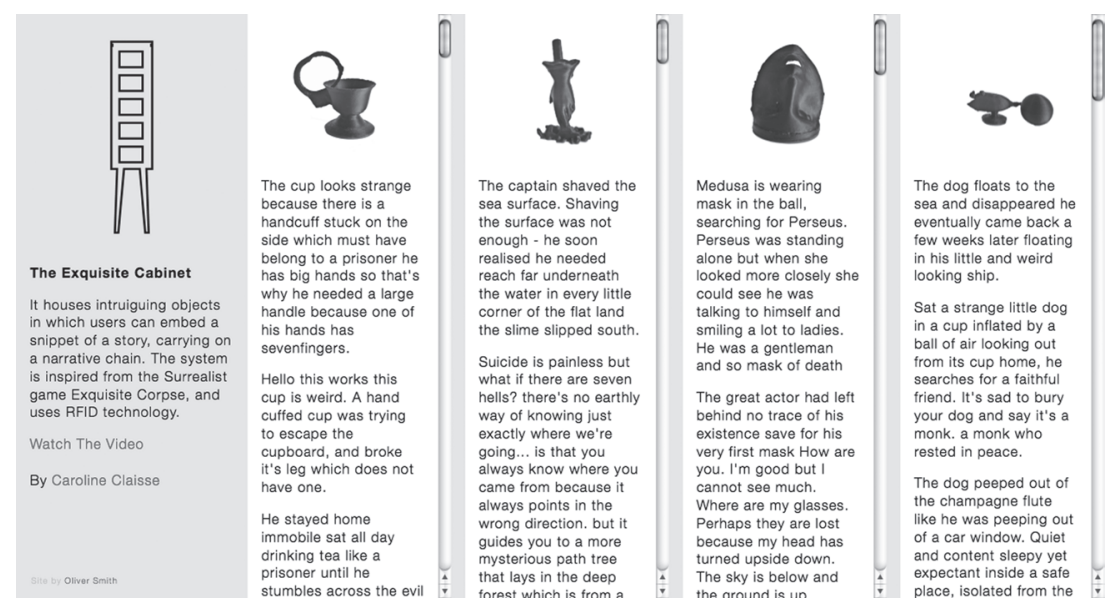

Figure 10

The Exquisite Cabinet. Online platform.

[Screenshot from exquisitecabinet.co.uk].

The snippet of stories collected over the show were visible in both the exhibition space (printed stories) and online as shown on figure 10.

\section{Conclusion}

The paper has shown how research and experiment fed into The Exquisite Cabinet. The research from my dissertation informed my creative practice, and my process developed organically from theory and research to experimentation, prototyping, and final installation. This body of work demonstrates the ideas explored throughout my MA Information Experience Design at the Royal College of Art in 2014. Prompting imagination in gallery settings with the use of touch and artistic methods (e.g. surrealist methods) shows an avenue which I believe is still to be explored. The themes of creative inquiry, tactile encounters and stories were explored in different ways, especially with the final installation which emphasises the potential of technology in contributing to such experience. Indeed, this research encouraged me to open further avenues for investigating the role of tangible technologies in enabling new forms of visitor interaction and participation (e.g. manipulation of physical objects digitally augmented), fostering new ways of thinking. More specifically, I would like to explore ways in which content generated by visitors can have a direct contribution to the exhibition and be more visible in the gallery space (e.g. direct feedback). With The Exquisite Cabinet, the use of tangible technology (e.g. RFID tags) enabled the collection of visitors' responses into a chain of stories which was printed and displayed online as an Exquisite Corpse. This project initiates ideas in how tangible technologies can be designed to promt visitors' imagination and contribution in gallery space and questions how content generated can be used by museum in meaningful and visible ways in the gallery space. 


\section{La pratique créative stimulant l'imagination et le partage d'histoires dans l'espace muséal}

Cet article fait état de la recherche et de la pratique créative entreprises dans le cadre d'un Master en 'Information Experience Design' à la Royal College of Art (Londres, R-U). La production introduite dans cet article cherche à démontrer comment la pratique créative peut encourager l'imagination et le partage d'histoires à travers la création de matériaux tangibles. Trois sections, allant de la recherche à la pratique, structurent l'article.

La première section, " Recherche de fond ", introduit mon mémoire intitulé Interpretive handling objects for mediating experiential learning in gallery settings, dans lequel je témoigne du rôle de praticiens créatifs agissant en tant que médiateurs entre le musée et les visiteurs, par le biais de la manipulation interprétative d'objets offrant aux visiteurs la possibilité d'une exploration sensorielle menant à la connexion avec les ouvres exposées. Cette recherche avait pour étude de cas l'Object Dialogue Box, une collection d'objets créés par des artistes et utilisés dans l'espace d'exposition pour faciliter l'apprentissage expérientiel. Créé pour différentes institutions culturelles par le partenariat artistique Karl et Kimberley Foster (hedsor), l'Object Dialogue Box peut être utilisé comme méthode alternative pour amener les visiteurs à exprimer et à partager leurs expériences et leurs pensées, entre eux et avec l'institution. Cet exemple démontre le potentiel du toucher dans l'espace d'exposition et comment l'apprentissage expérientiel peut être stimulé par le biais d'expériences créatives, participatives et tactiles.

La section «Design Experiment " présente The Monk's Parlour Kit, une trousse à outils conçue pour encourager les participants à développer leur interprétation personelle dans le contexte muséal. Elle est caractérisée par une série d'activités pratiques qui ont été menées pendant le mois d'avril 2014 au musée Sir John Soane de Londres (R-U). À la suite d'une visite au Monk's Parlour, huit participants ont eu l'occasion de réfléchir à leur visite en utilisant la trousse pour créer des artefacts expressifs, activité qui encourageait la conversation entre les participants et moimême. Cette section démontre comment, par le biais de la fabrication, une perspicacité personnelle et significative peut émerger.

Finalement, la section « Experimental Installation » présente The Exquisite Cabinet, une installation d'abord exposée en 2014 à Londres, à l'occasion de l'exposition des diplômés du Royal College of Art. Le cabinet mettait en montre quatre objets curieux dans lesquels les usagers étaient invités à intégrer des extraits de récits. Afin de stimuler l'imagination et le partage des récits, l'installation employait des méthodes empruntées à l'art surréaliste (tel le jeu du Cadavre exquis) et mettait à contribution des objets hybrides. Pendant le spectacle, le cabinet colligeait des récits du public pour chaque objet et ceux-ci étaient imprimés et conservés sur plateforme numérique. 